\title{
Understanding physical environment through safe highway transport mobility with special review on climate - the highway route Belgrade-Novi Sad, Serbia
}

\author{
Ivana Sentić A* $^{*}$ Tijana ĐorđevićB \\ Received: October 25, 2018 | Revised: December 26, 2018 | Accepted: December 27, 2018
}

DOI: $10.5937 / g p 23-19285$

\begin{abstract}
This paper focuses on the highway corridor Belgrade-Novi Sad, Serbia and the relationship between the highway and surrounding nature, as an integral part of the spatial entity which the highway belongs to. The paper emphasizes a high importance of studying the physical-geographical factors in the process of highway construction in order to achieve high level of traffic safety. Particular attention was directed to climate elements - the factors that are not so visible, but still may pose a great risk to road safety. Data were taken from CARPATCLIM database and their evaluation was confirmed by the data obtained from CHEK-LISTS. It was found that the climate elements have a strong influence, but it can be successfully controlled by vegetation. Landscape design of both sides of the highway may offer a possibility of mitigating the influence of climate elements, which was also pointed out in the paper.
\end{abstract}

Keywords: physical-geographical factors, climate elements, highway, traffic safety, highway landscape

\section{Introduction}

Physical geography studies spatial factors and provides analysis of an interaction of spatial natural phenomena with human activities, as well as human influence on the environment (Gabler, 2015). With spatial planning, the influence of physical-geographical factors can be altered and adjusted to the needs of people, but it can never be completely eliminated. Therefore, in traffic planning, it is necessary to study and analyze the most important physical-geographical factors, such as: geological characteristics, characteristics of relief, climate characteristics, hydrological characteristics, and characteristics of soil structure, plants and animals
(Kicošev, 2007). Although traffic planning is predominantly an engineering discipline, because of the validity of design (not to expose the road to landslides, floods, etc.), the physical-geographical studies must be done (Đorđević, 2004). These studies should include a preliminary phase (the choice of route for the road corridor) and field research. Preliminary phase is characterized by: geomorphological analysis of the terrain (preliminary determination of the route, depending on prominent natural obstacles); checking a selected corridor in cooperation with an engineering geologist and a traffic engineer and calculation of preliminary costs

A University of Novi Sad, Faculty of Agriculture, Department of Fruit growing, Viticulture, Horticulture and Landscape architecture, Trg Dositeja Obradovica 8, 21000 Novi Sad, ivanab@polj.uns.ac.rs

B University of Novi Sad, Faculty of Sciences, Departmentof Geography, Tourism and Hotel Management, Trg Dositeja Obradovica 3, 21000 Novi Sad, dordevictijana@gmail.com

* Corresponding author: Ivana Sentić, e-mail: ivanab@polj.uns.ac.rs, phone: +38121485 3322 
of the field research, design and construction. On the other hand, field research includes: geotechnical and geomorphological analysis of soils, rocks and terrain slopes; hydrological characteristics and climate research, as well as topographic control of the central axle of the road (Doornkamp, 1985).

Landslides, rock erosion, floods, exposure to winds, snow deposits, as well as passes through wildlife habitat areas are just some of the phenomena that could endanger traffic safety. Therefore, knowing these occurrences can save a lot of time and money in traffic planning.

Earlier research of physical-geographical factors and their influence on traffic planning and road construction has led to the conclusion that adequate landscape arrangement can be an important element that will reduce or mitigate negative impacts of physical-geographical factors. If it is properly selected and well located in a landscape, vegetation can play a major role in controlling traffic safety. Proper selection of plants is very important, especially when it comes to their specific role in a landscape (erosion, wind exposure, snow deposits, etc.). In order not to destabilize driver's safety and to respect physical-geographical factors, it is very important how far away from the road and in what kind of groups the plants should be planted (Crowe, 1960). Off course, traffic safety cannot always be solved by using natural elements i.e. vegetation. In certain cases, it is necessary to look at the technical constructive possibilities. However, among all the physical-geographical factors, the climate elements are the ones that can be successfully controlled with an adequate vegetative assembly, adapted to the natural conditions of the whole area through which the road corridor passes.

Climate changes can have a major impact on traffic engineering. Even 30 years ago, Western European countries (in particular Great Britain), Scandinavian countries, as well as USA and Canada, began heavily investing in exploring a new science - road meteorology. This science aimed to establish a road information system about weather conditions, especially in those areas where climate and weather conditions often endanger or interrupt normal traffic flows. In addition, it is of particular importance to anticipate the possibility of ice occurring on the roads by producing local climate models while monitoring the movement of air temperature and the structure of pavements, as well as other relevant parameters (Thornes, 1989; Đorđević, 2004).

Climate elements that have been emphasized the most, in regards to the impact on traffic safety are: wind direction and speed, intensity and form of precipitation, snow depth, relative air humidity (significant for fog) and temperatures (Lorenz, 1980; Đorđević, 2004). Climate elements also include: solar radiation, air pressure, evaporation, cloudiness and sunshine (Dukić, 1998). However, since these have no noticeable impact on the traffic safety (considering only land traffic transportation), they have not been taken into consideration in this research.

Wind can be considered the most influential climate element in terms of traffic safety. It exerts its influence independently or in a combination with other climate elements, thus enhancing their effects. Only a few hours of extreme wind during the day may be more than enough to cause great troubles for the drivers. Furthermore, if extreme wind occurs for several days in row, the consequences may be even greater. A significant percentage of traffic accidents in the world occur when it rains. Although traffic intensity is reduced in rainy weather conditions, as the amount of precipitation increases, so does the number of traffic accidents. As regards to the impact of snow on traffic activity, the forecasting of snowfall plays a major role in creating a roadmap management and maintenance plan in winter months, especially in windy areas. Snow is mostly carried by wind. In this process, obstacles can be vegetation or terrain topography (Perry, Symons, 1994; Edwards, 1996; Musk, 2003a). Fog, especially dense fog, is a climate element that presents the worst fear for the drivers on the road (Musk, 2003b). In heavy dense fog, the traffic intensity decreases to $20 \%$. It can be extremely dangerous, especially when visibility varies at shorter distances and especially in the so-called "black spots" of the road (Musk, 2003a; Musk, 2003b; Eisenberg, 2004). Extremely high or low temperatures are positively correlated with traffic accidents (Brijs et al., 2008). This correlation is further enhanced by joint effect of several climate elements. So, if at low temperatures, there are strong winds and it rains or snows, extremely dangerous driving conditions may occur on the road surface. On the other hand, hazardous driving conditions can also occur with winds of lower intensity and at lower temperatures, when there are suitable conditions for low precipitation.

\section{Theoretical background}

The influences of physical-geographical factors are almost always interconnected and conditioned; therefore, the approach to the research area should always be analytical, and subsequently assessed in a form of synthesis. However, McHarg (1995) points out that in highway engineering, the approach is increasing- 
ly more associated with analytical, rather than a synthesis approach. According to this author, the work on highway construction model should include the examination of three categories of factors: category 1 terrain slope and geological structure, also soil characteristics (some lands are more at risk of erosion than others, the amount of water in the soils, the need for drainage etc.); category 2 - study of danger zones for human life, such as areas exposed to floods, landslides or extreme winds; category 3 - evaluation of natural and social processes including the value of history, waters, forests, soils, as well as wildlife, visual and recreational values. Moran (2010) gave an example of disagreement of road and its surrounding area in the Britain. He pointed out that construction of the British highway was faced with several issues before completion of the first section in December 1958. Immediately after the opening, problems started to emerge. The road began to disintegrate and it retained a lot of water. The case of the British highway was not the only one. There was a lot of concern about the construction of numerous highways on slopes or in the floodplains (Pantelidis, 2001; Kumar Dahal, 2006; Kirkby, 2011; Franch-Pardo, 2017).

On the other hand, the influence of climate elements on traffic planning is insufficiently explored (Koetse, Rietveld, 2009; Theofilatos, Yannis, 2014). According to global reports (IPCC, 2014), climate change has been recognized as one of the greatest global challenges (Stojićević, 2016; Trbić et al., 2017). The temperature is increasing, the amount of precipitation becomes atypical for certain periods during the year, glaciers are melting and the global sea level is rising. Extreme weather conditions are expected to become more prominent; floods, droughts and strong winds will become more frequent and intense. Therefore, studying the influence of climate elements on various spheres of human activities and the environment has to be the field of interest for many different professions. Some studies on the influence of climate elements have already been initiated, such as: the effect of temperature and snow days on tourism movements (Stojsavljević et al., 2016); the impact of temperature and abundance of precipitation on the country's socio-economic development - the case of Kenya (Obaigwa Sagero et al., 2016); the influence of temperature, intensity of precipitation and wind speed on livestock development - the case of the Southwestern region (Havstad et al., 2018), etc. In terms of traffic planning, the most researched climate elements are precipitation and snow depth (Eisenberg, 2004; Bergel-Hayatet al., 2013; Theofilatos, Yannis, 2014). The effect of temperature on traffic safety is somehow less explored (Bergel-Hayatet al., 2013), the same as the impact of fog (Musk, 2003b), while the influence of wind on traffic safety is the least explored (Koetse, Rietveld, 2009; Theofilatos, Yannis, 2014).

It has been emphasized that one of the most important factors in traffic planning is studying the influence of climate elements at the macro level (data based on annual or monthly average values). Even more than that, it is important to study the impact of climate elements at the micro level. As McClatchey (2011) states, description of climate conditions of a particular site depends on the scale on which the climate is being researched. The smaller the researched geographical area is, the more important is the detail analysis of climate conditions. Authors such as Eisenberg (2004) and Hermans et al. (2006) concur and underline that traffic studies on macro level are useful for the purpose of adopting legal acts in spatial planning. Data processing at micro level allows deeper understanding of the problem. The results of this research are observed at the micro level, so their contribution to finding the solution for the problem is significant.

\section{Study area}

The highway corridor Belgrade-Novi Sad, located in the northern part of the Republic of Serbia, Autonomous Province of Vojvodina, is categorized as an IA category state road in Serbia. The highway corridor passes through a plain, a quite monotonous landscape, which is dedicated to agricultural production and is not perceived as a part of spatial entity in the human-vehicle-road-environment transport system. At the very start, the highway corridor passes through the plain area, which at the territory of the Inđija municipality shows rugosity of terrain. After crossing the Danube river, the highway corridor passes through a slightly stratified region, extending over the slopes of
Fruška Gora to continue as a flat route to Novi Sad. At the Danube river, the section passes through the special nature reserve "Koviljsko-petrovaradinski rit" (Figure 1).

The explored highway corridor overlaps with the European E-75 corridor, and represents a part of the Pan-European Transport Corridor X system - the Xb route (MULTILATERAL, 1983, "Official Gazette of the Republic of Serbia", No. 64/2015). It should be noted that during the construction, the highway corridor has been raised several meters compared to the original level. As such, it is exposed to the influence of the wind. 


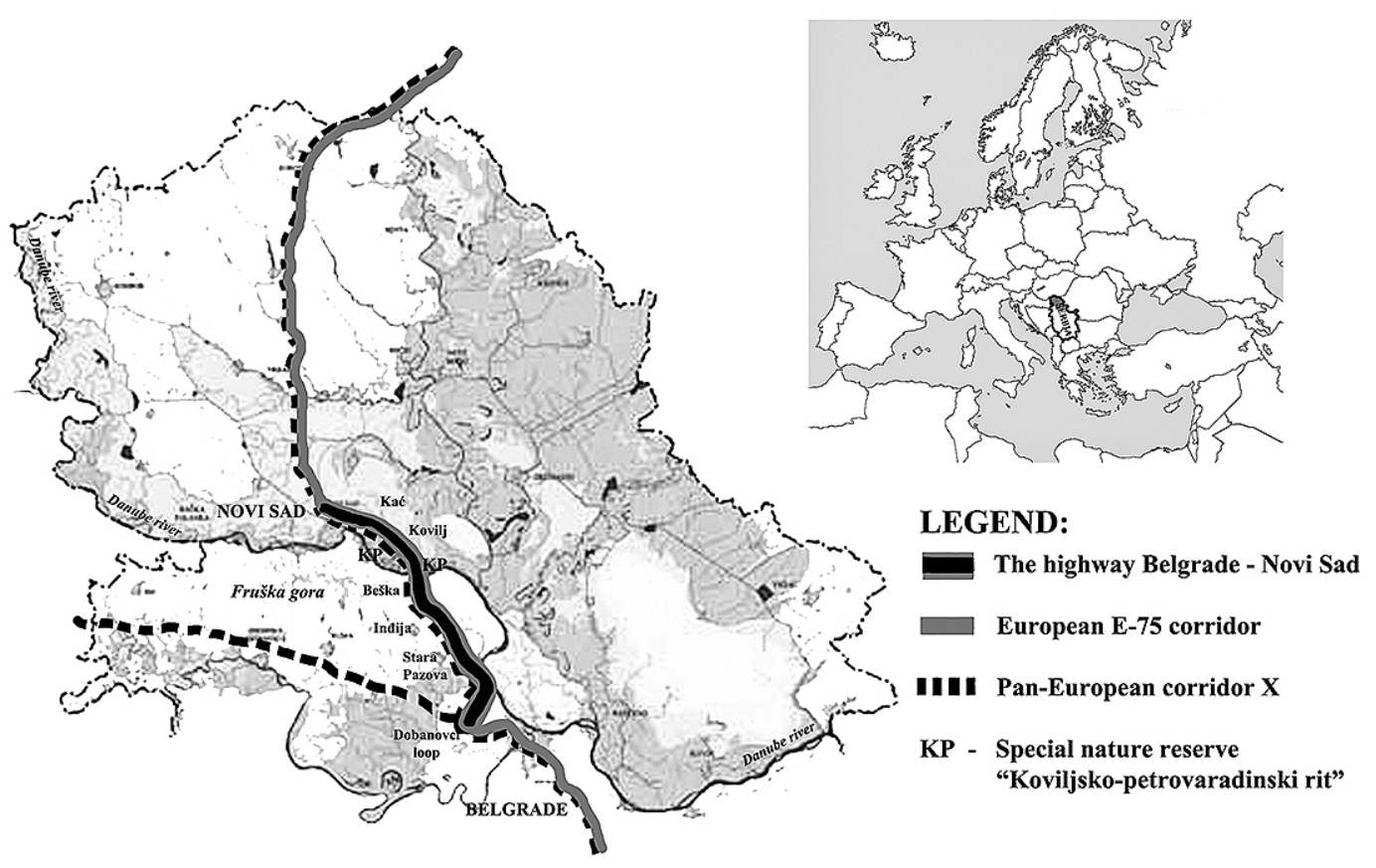

Figure 1. Overview of the explored traffic infrastructure corridor Belgrade-Novi Sad Source: Internet 1, processed by Ivana Sentić

Highway corridor Belgrade-Novi Sad connects the two largest cities in the country, but it also connects several important cities in Vojvodina as well. As part of the European network of roads, it is located on the transport line that connects Serbia with Hungary, and therefore, it has a special socio-economic significance for the state. In terms of vegetation, the area of the Vojvodina has changed dramatically since the mid-2oth century. Today, there is not much left from the former vegetation corridors and massifs along the meliorative canals and roads. Be- cause of the configuration of the terrain, in Vojvodina, all the roads were once elevated and followed by treelines. The reason for this was not to produce the shadow for vehicles, but to protect them from wind and snow. The most intensive raising of vegetation belts along the traffic routes was achieved in the 1960 (Vlatković, 1981). This image of the liner corridors along the roads is completely lost today. During the planning of the highway corridor Belgrade-Novi Sad, no plans for landscape design were made before, nor during its construction.

\section{Methodology}

Due to the extent of the problem, the first step in studying the impact of physical-geographical factors on traffic planning was to analyze the existing researches, studies, laws and regulations. Based on the evaluation of all the collected documentation and field research, it was concluded that in terms of traffic safety, climate elements represent one of the greatest dangers on highway corridor Belgrade-Novi Sad. At the same time, these are the least studied physical-geographical factors in traffic planning. Therefore, the next step was to focus on more detailed analysis of the influence of the climate elements on traffic safety. Among them, it has been estimated that the ones with the most noticeable impact are: wind direction and speed, intensity and form of precipitation, snow depth, relative air humidity (in this research important because of analyzing fog occurrence) and minimum and maximum temperature. Data were taken from CARPATCLIM: Climate of the Carpathian region database. Climatological grids covered the area between latitudes $44,8^{\circ} \mathrm{N}$ and $45,3^{\circ} \mathrm{N}$ and longitudes $19,8^{\circ} \mathrm{E}$ and $20,4^{\circ} \mathrm{E}$ for period of 1990-2010. Spatial resolution was $0.1^{\circ} \mathrm{x}$ $0.1^{\circ}$. In this way, climate data for any location within the latitude and longitude of the researched highway corridor was obtained. Data were further processed manually through in Excel program.

Wind speed values were grouped into three categories: $0-3,99 \mathrm{~m} / \mathrm{s} ; 4-8,99 \mathrm{~m} / \mathrm{s}$ and $\geq 9 \mathrm{~m} / \mathrm{s}$; for snow values: $1-5 \mathrm{~cm} ; 6-10 \mathrm{~cm}$ and $>10 \mathrm{~cm}$; and temperature: $<0^{\circ} \mathrm{C}, 1-30^{\circ} \mathrm{C}$ (physiological optimum of temperature for plants) and $>30^{\circ} \mathrm{C}$; while for intensity of precipitation, the data were summarized monthly and compared to monthly average values for Vojvodina. Relative air humidity data were processed by count- 
ing days with air humidity $\geq 93 \%$ (estimated value for fog occurence).

The obtained results were compared with the current situation in the field, through the implementation of CHECK-LISTS, carried through different weather conditions (clear, rainy, windy and snowy weather). Two types of checklists were made for both directions of the researched highway corridor (Belgrade-Novi Sad and Novi Sad-Belgrade). The goal was to examine parameters that have a direct impact on the traffic safety. The first type of check-list examined the impact of climate elements on the highway and the presence of technical elements that could control the impact of climate elements. The second check-list examined the presence of vegetation that could control the effects of climate elements on the highway. Both check-lists were evaluated qualitatively through assigned parameters for every $2-5 \mathrm{~km}$ of researched highway corridor.

The results of the entire research highlighted the most high-risk sections of the Belgrade-Novi Sad highway corridor, endangered by examined climate elements. Since the climate elements can be controlled by vegetation, the last step in the research was to give a proposal for vegetation design that would have a positive impact on the traffic.

\section{Results and Discussion}

By analyzing physical-geographical factors on the researched highway corridor, it was determined that the entire traffic route lies on loess and in the area of VI to VII strength degrees of seismological activities (European Macroseismic Scale, EMS-98), characterized by very strong and powerful earthquakes (Internet 2). The eluvial, fluvial and eolian relief prevail. However, near Beška settlement, just before the bridge that crosses the Danube river, deluvial-proluvial relief is visible (moderate soil erosion caused by water and appearance of gullies in the soil), as well as colluvium - slopes and landslides (Kosćal et al., 2005). The geographical region through which the highway corridor Belgrade-Novi Sad passes, almost entirely belongs to the Danube river basin; only an insignificant part near Dobanovci belongs to the Sava river basin. According to the Atlas of the Danube River (Danube Floodrisk Project, 2012), it can be perceived that one-hundredyear waters would have an impact on the landscape that the researched highway corridor passes through.

Among all the climate elements that have been observed, wind is the most dominant one. It can act independently or in combination with almost all other climate elements. The results showed that the second and the third category winds should be given extra attention, since these are the ones that can create dangerous situations and cause traffic accidents on the road. The greatest influence of the wind is felt in November and December (predominantly coming from the SE direction), as well as in March and April (predominantly coming from the NW direction). The strongest winds and the highest number of days with intense winds $(\geq 9 \mathrm{~m} / \mathrm{s})$ were recorded in the northern part of the researched highway corridor - sections near Kovilj and Kać, as well as at the start of the transport route near Batajnica. On the section from the town of Stara Pazova to Beška, since the area is open, without protective vegetation, the dominance of the wind is very pronounced, especially on the section between the town of Inđija and Beška. On the Beška Bridge over the Danube river, due to the open space, strong winds blow from different directions.

In terms of fog, results showed that January, December and November stand out as months with the highest number of days with relative air humidity of $93 \%$ and higher. January is the month when the winds at all geographical coordinates are losing their intensity, so the radiative fog frequency in this period of the year is understandable. Silences are not so common at the researched highway corridor, but they appear most frequently in January and December. At the same time, these are the months with the highest number of days with the radiative fog. The maximum number of days with relative air humidity of $93 \%$ and higher was recorded near Novi Sad (Coordinate No1) in January 1997 and 1999, as well as in December 2006, when it ranged from 14 to 15 days per month. At other geographical coordinates, an average number of days with fog in prominent months is about 10 days.

The amount of precipitation is not equally distributed along the entire highway corridor Belgrade-Novi Sad. In order to interpret the obtained data, based on data from the Hydrometeorological Institute of Serbia (RHSS, 2017) and according to research of Lalić et al. (2011), it was determined that the average amount per month is $50 \mathrm{~mm}$. According to this, a higher amount of precipitation (above the average) is recorded in the second half of the year in the period from May until the end of the year. The highest amount of rainfall is in June (average value of 75 to $90 \mathrm{~mm}$ ), and the least in February (average value of 30 to $35 \mathrm{~mm}$ ). Heavy rainfall is recorded at Batajnica site, section from Inđija to Beška and near Kać. By analyzing the obtained values for the intensity of precipitation in parallel with the values of wind strengths, higher deposits of precipita- 
tion on the highway are expected in the period from November to January.

The occurrence of snow is recorded in the period from November to March. The highest numbers of snowy days are in January, February and December; the smallest numbers of snowy days are in March and November. The months that have the highest snow depth $(>10 \mathrm{~cm})$ are January and February. It is noticeable that further away from Belgrade and closer to Novi Sad, the number of snowy days and the snow depth increase. The largest retention of snow, meaning the sections with the greatest number of snowy days are: sections of the highway near Stara Pazova, Kovilj and Kać. The other sections do not fall behind, since they have on average of 15 days per month with snow. December is the month with winds of high intensity, when the possibility of snowdrifts and snow retention on the highway is high, since there is no protective vegetation.

In general, considering all the geographical coordinates of the researched area, the results showed that the coldest months were January and February, followed by December. Temperatures below zero occur much less in March and on certain days in November. The average minimum temperatures in the winter months are predominantly about $-10^{\circ} \mathrm{C}$. Low precipitation can be expected to intensify in January and
February, and then in the second half of December. From April to September, the dominant mean monthly values are between 1 and $30^{\circ} \mathrm{C}$, which is favorable for the physiological development of plants. The hottest months are July and August.

Observation of average values for all the researched climate elements resulted in several conclusions (Table 1). At the beginning of the highway corridor, near Batajnica, winds have a high intensity. Furthermore, in the winter months, there is a noticeable amount of precipitation followed by very low temperatures, which makes this spot very dangerous. The conditions for occurrence of low precipitation are very favorable in January and February. There are not a lot of foggy days. The situation is not much different in the northern part, where larger amounts of snow are observed and snow retention periods are longer, which is justified, due to the occurrence of high intensity winds and very low temperatures in the winter months. In the central part of the route, in the area between Stara Pazova and Beška, an increased number of days with relative air humidity of $93 \%$ and higher (foggy days) is evident. Those days were mainly noted in November, December and January. The extremes of the researched climate elements were shown in the graphs in Figure 3. Locations of the geographical coordinates at the researched area through assigned ordinal num-

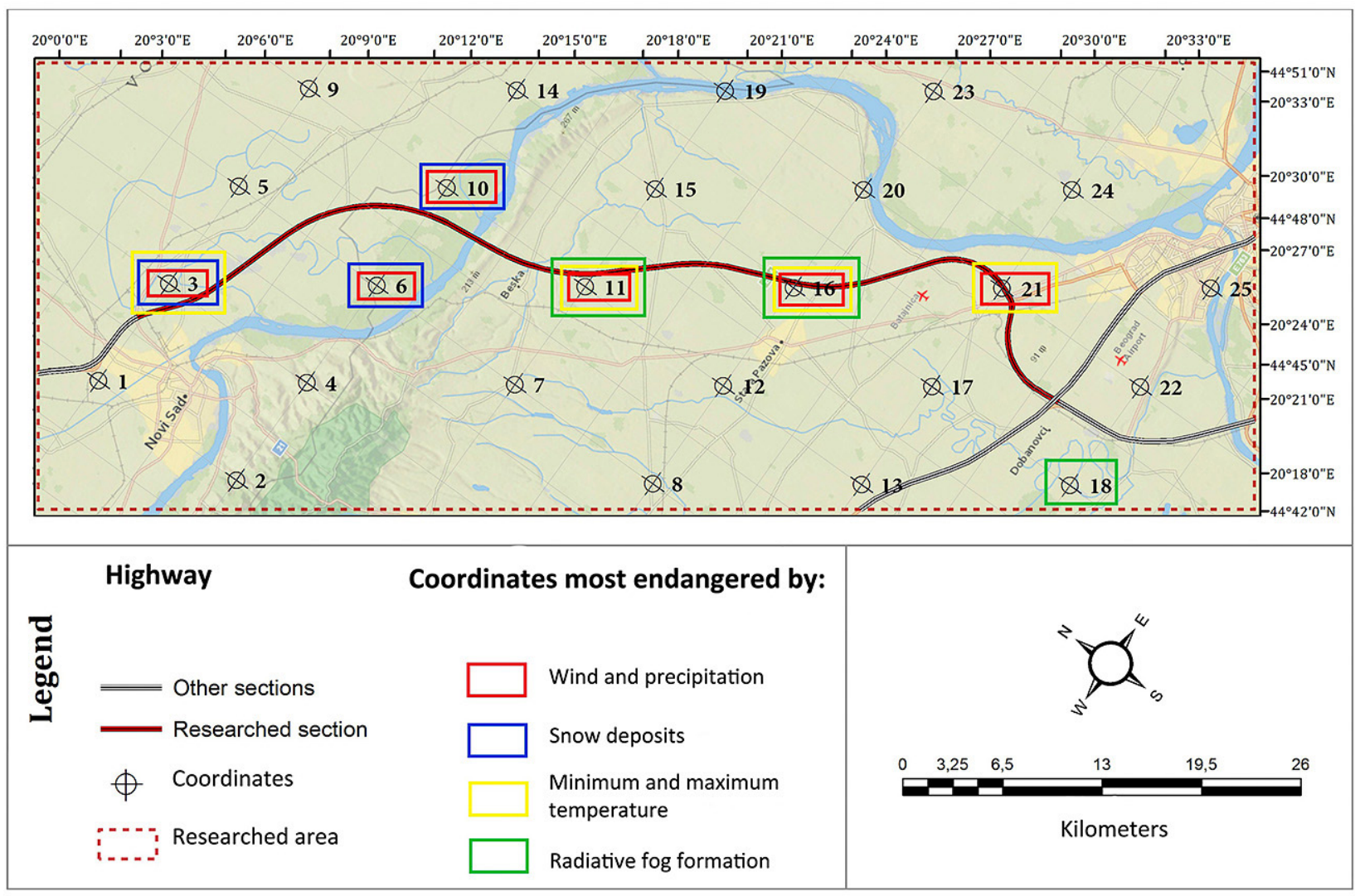

Figure 2. Geographical position of the extremes of the prominent climate elements Source: Tijana Đorđević 
Table 1. Average monthly values for the extremes of prominent climate elements at the researched geographical coordinates in the period $1990-2010$.

\begin{tabular}{|c|c|c|c|c|c|c|c|}
\hline № & $\begin{array}{l}\text { geographical } \\
\text { coordinates }\end{array}$ & $\begin{array}{l}\text { wind } \\
(\mathrm{m} / \mathrm{s})\end{array}$ & $\begin{array}{l}\text { precipitation } \\
\quad(\mathrm{mm})\end{array}$ & $\begin{array}{l}\text { snow } \\
\text { (number of days in a } \\
\text { month with snow from } \\
\text { December to March) }\end{array}$ & $\begin{array}{l}\text { relative air humidity } \\
\text { (number of days in a } \\
\text { month with relative air } \\
\text { humidity } \geq 93 \% \text { ) }\end{array}$ & $\begin{array}{c}\min \mathrm{T} \\
\left({ }^{\circ} \mathrm{C}\right)\end{array}$ & $\begin{array}{c}\max T \\
\left({ }^{\circ} \mathrm{C}\right)\end{array}$ \\
\hline 1. & $19,8 / 45,3$ & 8.89 & 119.30 & 16.29 & 8.14 & -11.62 & 29.44 \\
\hline 2. & $19,8 / 45,2$ & 13.15 & 117.7 & 15.93 & 5.66 & -10.56 & 29.53 \\
\hline 3. & $19,9 / 45,3$ & 10.52 & 117.77 & 17.64 & 8.14 & -11.52 & 27.74 \\
\hline 4. & $19,9 / 45,2$ & 10.26 & 115.46 & 19.57 & 12.72 & -6.72 & 28.60 \\
\hline 5. & $20,0 / 45,3$ & 9.99 & 116.56 & 17.68 & 8.83 & -11.57 & 29.68 \\
\hline 6. & $20,0 / 45,2$ & 7.51 & 115.75 & 18.57 & 8.41 & -7.65 & 29.33 \\
\hline 7. & $20,0 / 45,1$ & 8.42 & 115.66 & 16.75 & 5.93 & -9.19 & 30.51 \\
\hline 8. & $20,0 / 45,0$ & 8.26 & 109.24 & 17.14 & 11.24 & -11.08 & 30.07 \\
\hline 9. & $20,1 / 45,3$ & 10.29 & 113.88 & 17.50 & 7.28 & -11.37 & 29.23 \\
\hline 10. & $20,1 / 45,2$ & 9.16 & 117.23 & 17.82 & 7.31 & -11.61 & 29.12 \\
\hline 11. & $20,1 / 45,1$ & 9.03 & 118.25 & 16.29 & 9.41 & -9.84 & 30.19 \\
\hline 12. & $20,1 / 45,0$ & 8.50 & 112.88 & 16.86 & 9.86 & -11.05 & 29.61 \\
\hline 13. & $20,1 / 44,9$ & 8.50 & 114.3 & 16.36 & 9.31 & -11.32 & 29.59 \\
\hline 14. & $20,2 / 45,2$ & 9.22 & 115.54 & 17.25 & 7.66 & -11.51 & 27.43 \\
\hline 15. & $20,2 / 45,1$ & 9.40 & 117.81 & 17.00 & 6.24 & -7.00 & 28.11 \\
\hline 16. & $20,2 / 45,0$ & 9.04 & 114.84 & 17.00 & 9.66 & -10.91 & 27.95 \\
\hline 17. & $20,2 / 44,9$ & 8.53 & 116.13 & 15.71 & 8.69 & -10.92 & 27.77 \\
\hline 18. & $20,2 / 44,8$ & 8.96 & 116.64 & 15.11 & 9.21 & -10.85 & 27.78 \\
\hline 19. & $20,3 / 45,1$ & 9.42 & 114.07 & 16.75 & 7.62 & -11.41 & 27.64 \\
\hline 20. & $20,3 / 45,0$ & 9.67 & 115.44 & 17.07 & 8.45 & -10.81 & 28.01 \\
\hline 21. & $20,3 / 44,9$ & 9.63 & 119.12 & 15.68 & 7.76 & -10.61 & 27.92 \\
\hline 22. & $20,3 / 44,8$ & 8.52 & 120.62 & 14.36 & 8.45 & -10.66 & 28.37 \\
\hline 23. & $20,4 / 45,0$ & 9.38 & 117.74 & 16.00 & 8.17 & -10.99 & 27.61 \\
\hline 24. & $20,4 / 44,9$ & 9.38 & 118.36 & 16.43 & 9.59 & -10.64 & 27.84 \\
\hline 25. & $20,4 / 44,8$ & 9.74 & 120.26 & 13.71 & 4.24 & -9.57 & 28.37 \\
\hline
\end{tabular}

bers were shown at Figure 2, with the extremes being specially marked.

In order to confirm the results obtained from CARPATCLIM database, it was necessary to perform the field work. The chosen days were the ones when the prominent climate elements occurred a bit more intensely: dry and sunny weather, occurrence of the fog, slight, moderate and strong winds with and without precipitation and snow. Results of CHECK-LISTS positively evaluated the results obtained from CARPATCLIM database. They confirmed that on the highway the influence of the wind is most often felt in combination with precipitation and snow. The sections that are the most sensitive to the effects of these climate elements are: part of the transport corridor near Batajnica, section from Stara Pazova to Beška, bridge across the Danube river near Beška and section near Kać. Furthermore, on these parts of the highway, there were visible soil deposits from the surrounding fields (Figure 4).
CHECK-LISTS pointed out that there is very scarce vegetation that cannot have a significant impact on mitigation of the dangerous effects of the researched climate elements. Vegetation that can be seen includes: crops, shrubs, adult woody species in a form of smaller or larger groups (forests) or solitaire trees. The densest vegetation is observed in the northern part of the highway corridor in the wetland area - special nature reserve Koviljsko-petrovaradinski rit, then section near Novi Sad, where there are forests, smaller groups of trees, as well as poplar plantations (Figure 5b, Figure 5c). Windbreaks have not been spotted. A positive example of vegetation is form of shrubs in the median strip near Stara Pazova (Figure 5a). This linear form of vegetation is properly positioned, because it reduces the reflection of lights from the opposite direction.

CHECK LISTS pointed out several dangerous spots. The first one is near Batajnica, where the road surface is severely damaged, there is a dumpsite nearby and 
The average values of wind extremes at the researched geographical coordinates

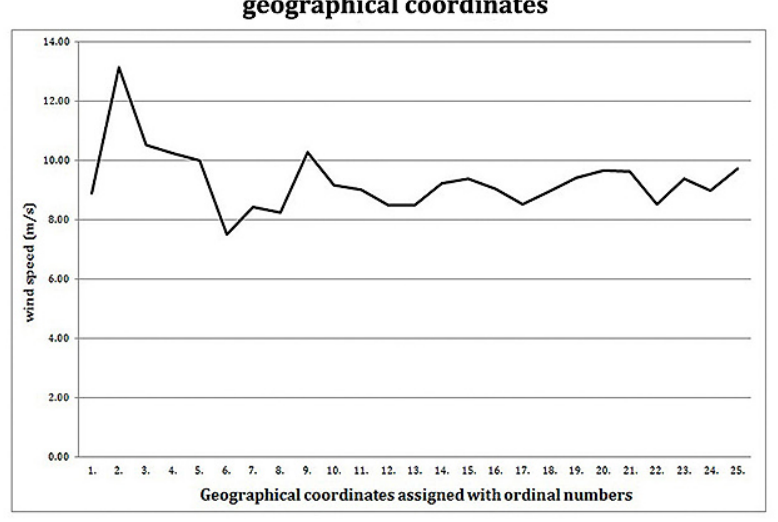

The sum of precipitation above average value at the researched geographical coordinates

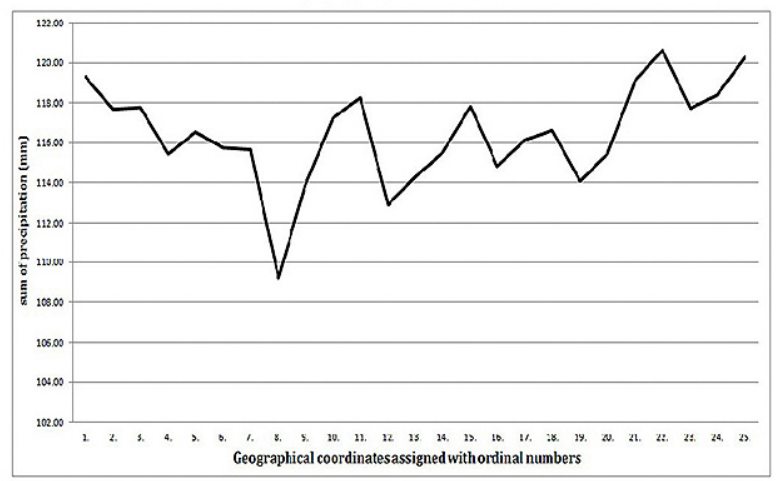

The mean values of minimum temperatures at the researched geographical coordinates

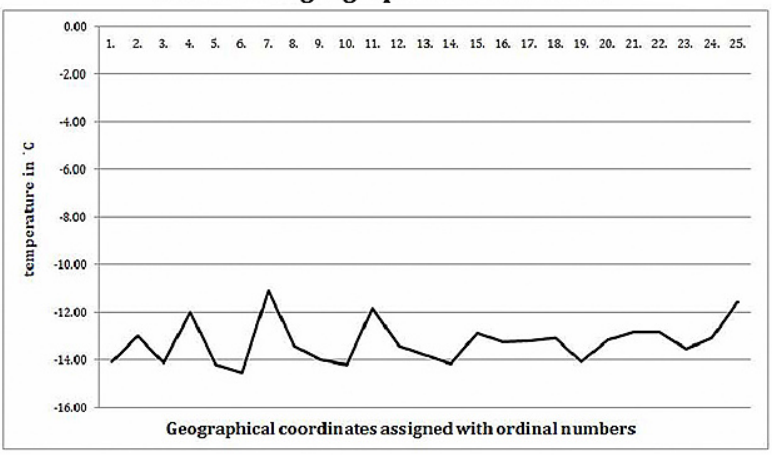

The frequency of increased number of foggy days at the researched geographical coordinates

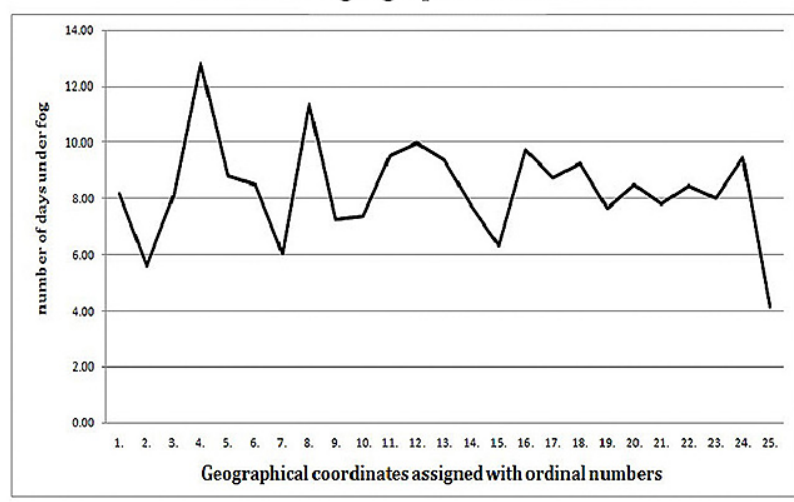

The frequency of increased number of days with snow at the researched geographical coordinates

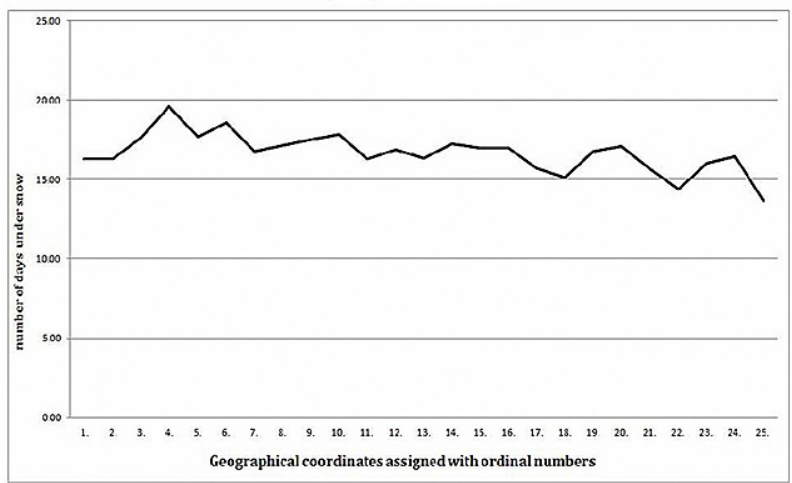

The mean values of maximum temperatures at the researched geographical coordinates

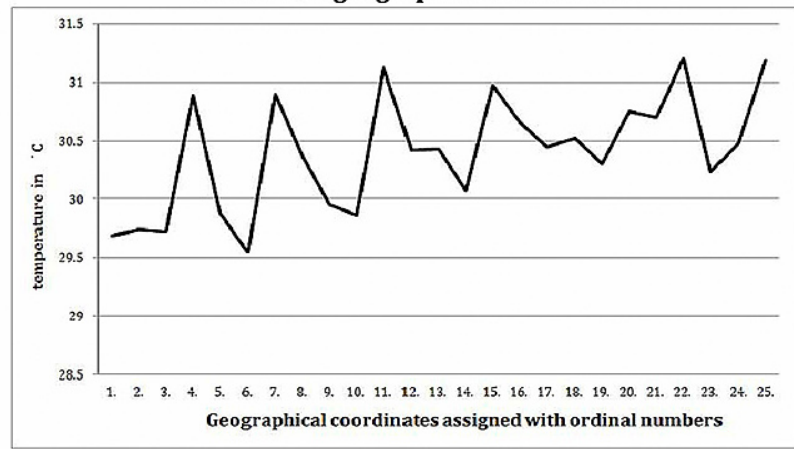

Figure 3. The extremes of the prominent climate elements in the period 1990 - 2010 Source: Ivana Sentić

the winds are strong, especially under the overpass (Figure 6a). There are several highway exits covered in vegetation in a way that actually reduces and disturbs the traffic safety (Figure 6b and Figure 6c).

Technical or natural elements in the area that would reduce the wind speed and prevent deposits of snow on the highway have not been noticed. An exception is the noise barrier wall near Dobanovci interchange $-8.3 \mathrm{~km}$ from the starting point, direction from Belgrade to Novi Sad. On snowy days in front of the wall on the road surface, snow deposits were observed (Figure 7). It is noted that the snow depth in the channels that follow the highway corridor was roughly $5-10 \mathrm{~cm}$ in both directions. The exception is the city of Indija where in certain places the snow depth is even greater. The main problem on snowy days is the emergency stopping lane, which is covered in snow, so there is a large possibility of slipping into the channel. On foggy days, the danger on the road becomes even greater. Very often, the fog spots, horizontal road 


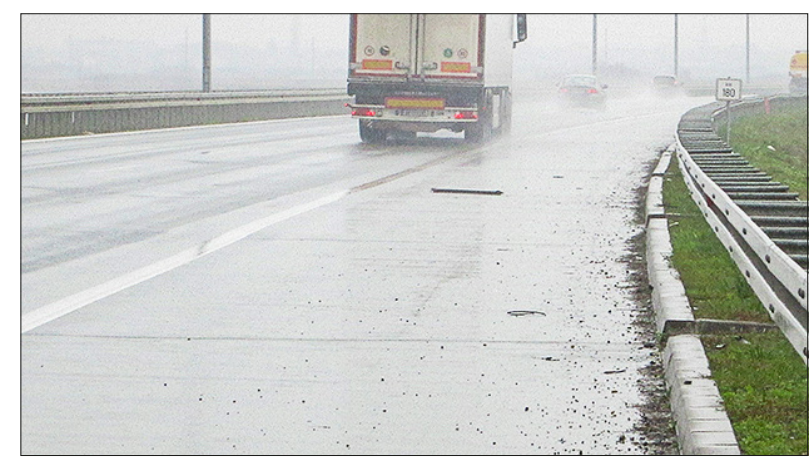

a. Immediately after the Dobanovci interchange in the vicinity of Batajnica - influence of rain and strong wind, good conditions for deposit of soil materials on the highway, BG-NS direction

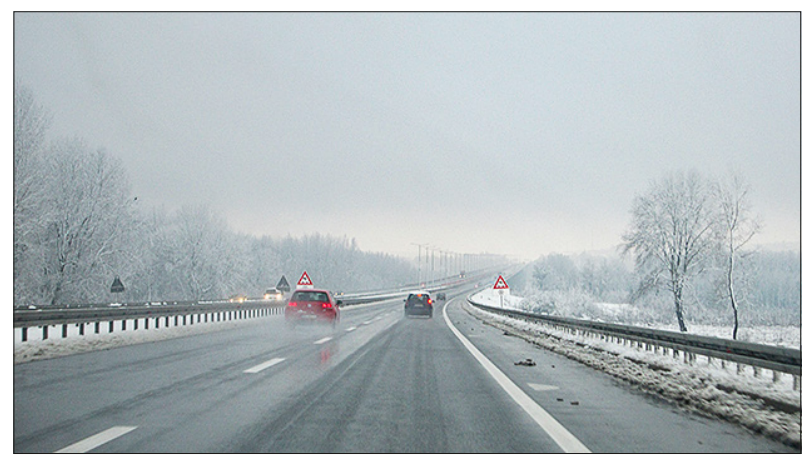

b. Beška Bridge - snow and frozen snow deposits on the highway, NS-BG direction. Deposits could be from the adhesion on vehicles or the influence of wind

Figure 4. Different deposits on the highway in various weather conditions Source: Ivana Sentić

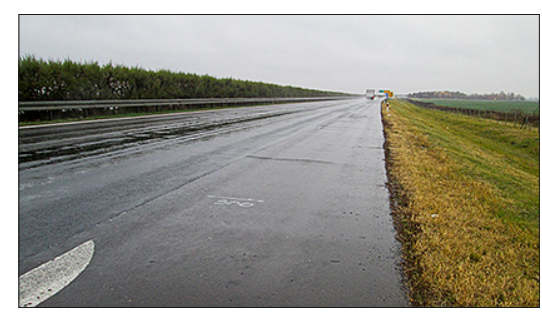

a. Shrub species in median lane, near Stara Pazova - BG-NS direction

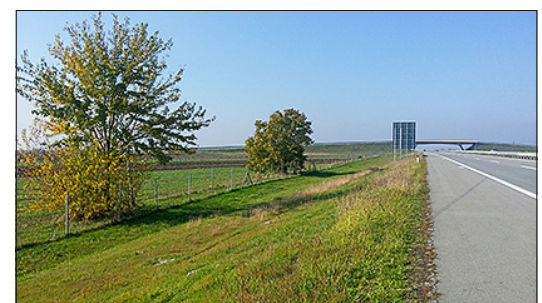

b. Solitaire trees along highway corridor NS-BG direction

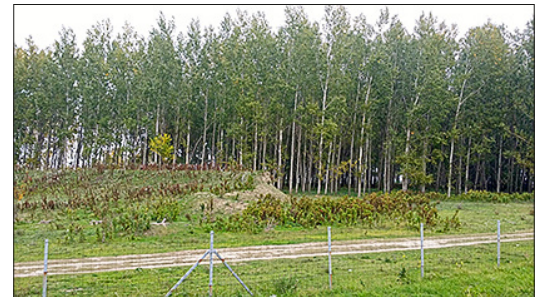

c. Poplar forest plantation just before the entrance to Novi Sad - BG-NS direction

Figure 5. Vegetation along the highway corridor Belgrade-Novi Sad Source: Ivana Sentić

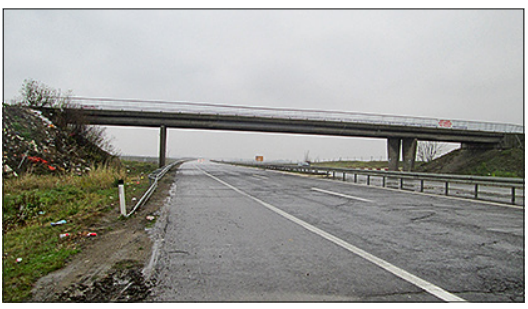

a. Dumpsite near Batajnica - BG-NS direction

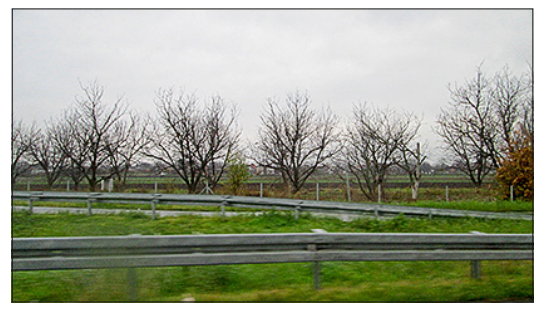

b. The exit lane for Kovilj - NS-BG direction

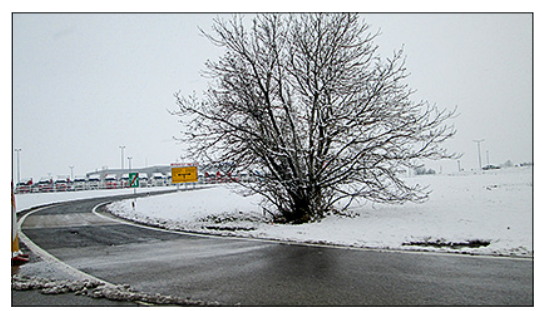

c. The exit lane for Batajnica - NS-BG direction

Figure 6. Dangerous spots that endanger traffic safety on the highway corridor Belgrade-Novi Sad Source: Ivana Sentić

signs on the emergency stopping lane, cannot be easily seen, and the traffic flow on the highway becomes even more difficult (Figure 8).

Wildlife crossings have not been noticed on the highway. Finally, cracked and damaged road surface is observed almost along the entire highway corridor Belgrade-Novi Sad, especially on the section from Belgrade to Beška (particularly near Batajnica and Stara Pazova). This can be a major problem, because on rainy days, holes in the roadway can be filled with water, which can freeze, if the temperatures are low.

Summarizing all the obtained results, it can be said that wind is the most dominant climate element. If the wind is blowing in the direction of the movement of vehicles, they will get specific speed and vice versa. On the other hand, if the wind is blowing orthogonal to the direction of the road, it will bring more inconvenience and potential danger to drivers. Therefore, afforestation could be a solution. Raising the windbreaks in the landscape is crucial, especially on the side of the road where strong wind is expected.

When the wind at the ground level (directly above the surface of the earth) approaches the windbreak, it changes direction and speed (due to vegetation obstacles). Depending on the obstacle and its location, the structure of the wind is changing - there is intense turbulence and the wind is forced to rise above the vegetation obstacle - the forest. The wind streams are spreading, descending and reaching the surface of the earth at some distance. Depending on the density of the forest zone, a larger or a smaller part of the air mass rises and exceeds the forest, while the oth- 


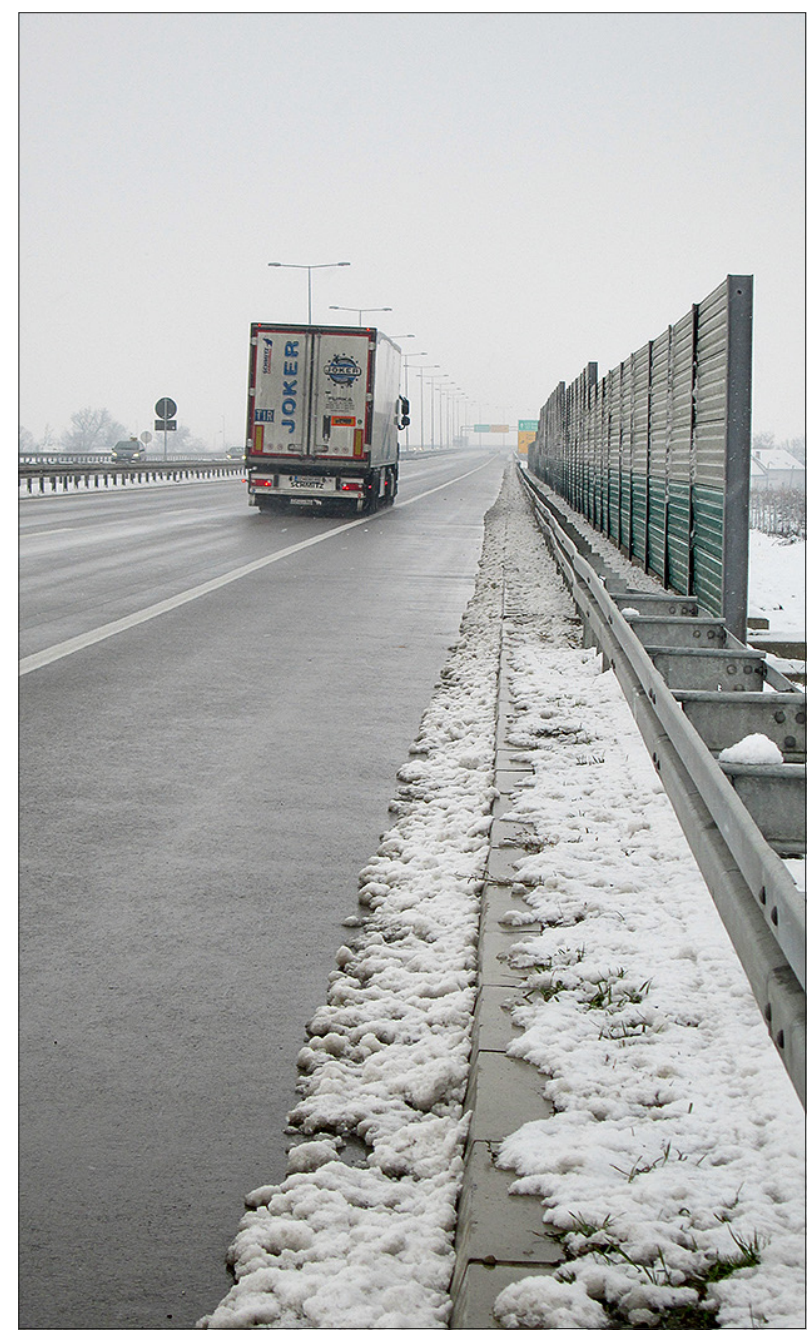

Figure 7. Noise barrier wall at the Dobanovci interchange keeps snow in front of panels - NS-BG direction Source: Ivana Sentić

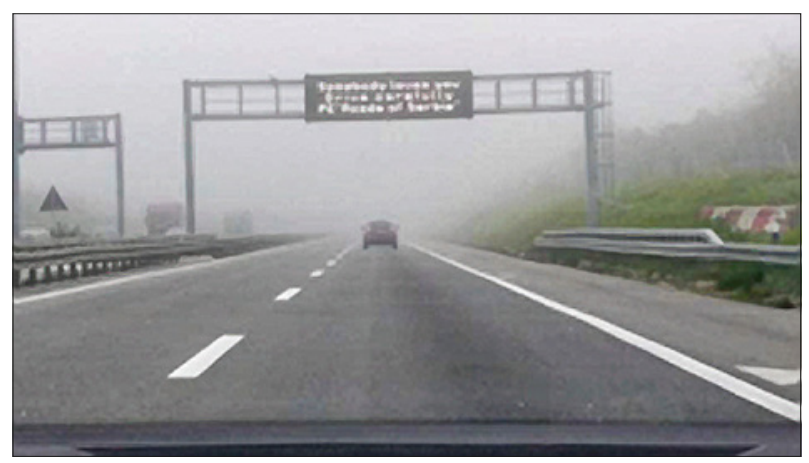

Figure 8. The radiative fog on the highway corridor just across Beška Bridge - NS-BG direction Source: Ivana Sentić

er one penetrates it up to a certain depth. Immediately behind the windbreak, a "sheltered area" is created, where wind speeds are reduced, but vortexes appear on horizontal axis. The higher the wind speed is above the forest, the more intense is the vortex behind it (Figure 9). Properly formed windbreak provides sheltered area of up to 30 times the wood height $(\mathrm{H})$, and the protection on the front side is in the zone of 5 to 10 times of the highest tree in the forest (Alemu, 2016).

Generally, this is how protection against strong winds and wind impacts is provided. On the other hand, by retaining snow, the windbreaks protect the land from deep freezing. Snow can be an extremely dangerous natural phenomenon on the roads, whether it's snowing or it is being accumulated on the road and beside it. The surrounding vegetation and road structures play a major role in solving this problem. Vegetation should be far enough from the road surface, in order to provide large enough zone for snow

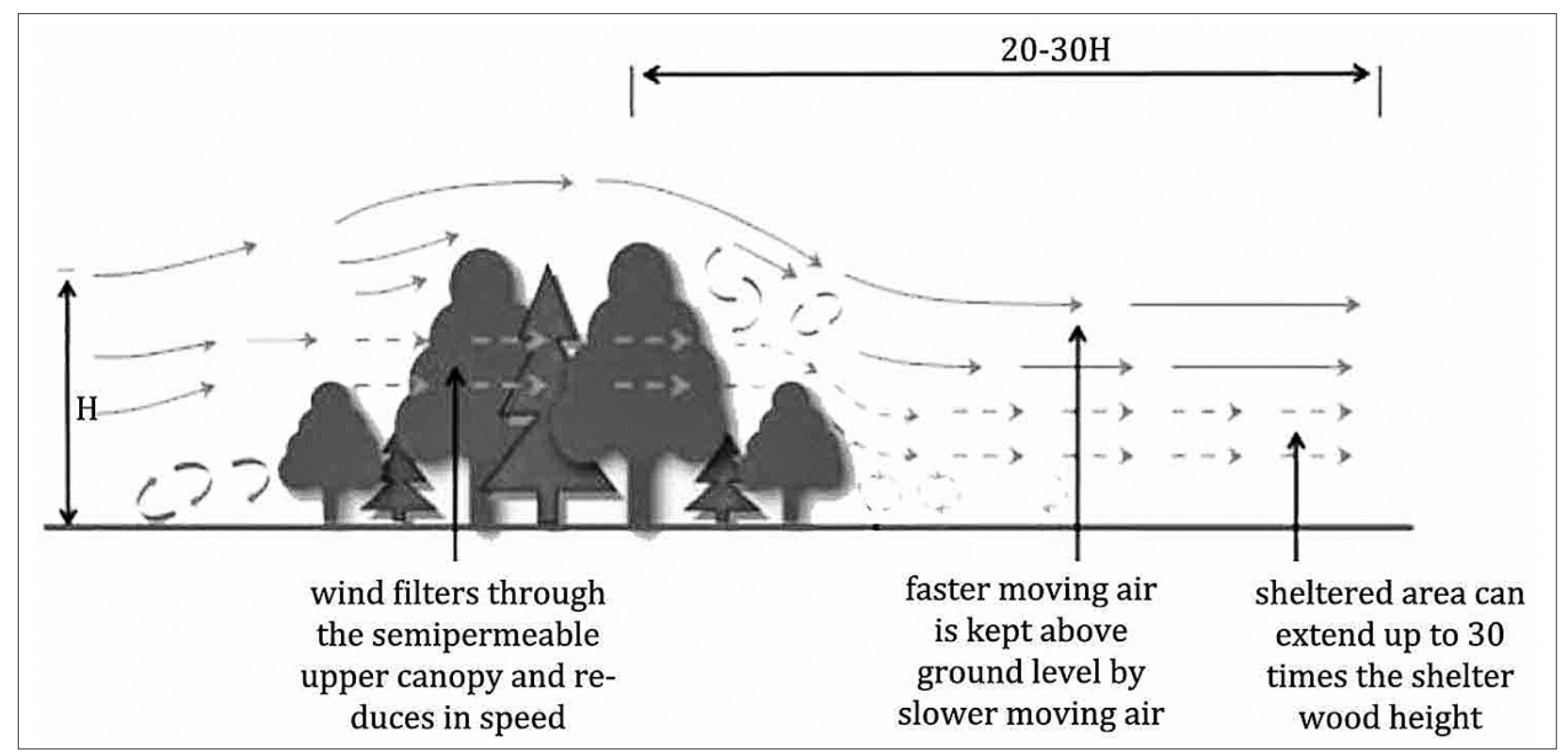

Figure 9. Windbreak design

Source: Alemu, 2016: 11 
deposits between vegetation and roadway, so that the snow deposits cannot reach the road. The plantation of high vegetation along the roadway should be avoided, due to the shadow it creates. This reduces the degree of snow melting and creates ice on the roadway, which again opens the question of road safety. On the other hand, vegetation that is planted too close to the roadway can cause a great danger, because of the breaking branches, pavement being raised by root system, falling leaves on the road surface and so on. Vegetation can also serve as a landmark, in case of lower visibility in fog conditions.

\section{Conclusion}

Based on what has been stated so far, it can be concluded that traffic engineering should not be understood as a rough determination and construction of a road corridor between place A and place B. Road construction should include relevant physical-geographical studies, in order to prevent exposure to landslides, strong winds, snow deposits, water retention on the surface, etc. The costs of maintaining roads that have been constructed without considering the above-mentioned studies can be unreasonably high and the consequences on human lives catastrophic. Such roads are not worth using and every effort invested in its construction is useless. Therefore, a study of physicalgeographical factors should be a mandatory requirement prior to the planning of road construction.

Safety is certainly a priority in road engineering of any type. The influence of climate elements on the traffic safety is not small or negligible. It is unjustified that this physical-geographical factor is neglected and insufficiently explored. Climate elements may not be so visible, but they are certainly very notable. The impact that they can have on traffic, unfortunately, can also lead to the loss of human lives.

Sometimes the effect of one factor does not cause so much trouble, but very often they join together and can cause great difficulties for drivers (Musk, 2003a; Koetse, Rietveld, 2009). The results of this study confirm the consistency of the conclusions of the prominent authors, as the wind showed up as the most dominant climate element on the explored highway corridor (the impact is felt almost on the entire highway). Its combined effect with precipitation and snow is noticeable. In the northern part of the researched highway corridor, wind speeds of up to $16 \mathrm{~m} / \mathrm{s}$ have been recorded. The wind is short lived, but sometimes it can have an extremely intense effect. In just a few hours it can make a complete collapse on the highway. Such data should certainly be recorded in order to raise awareness of the situation that climate elements may cause.

It has been confirmed that the explored highway corridor is very susceptible to the influence of climate elements, both left and right side of the highway. The situation is understandable because there is no protective surrounding vegetation. The highway landscape is exposed to wind erosion, so raising the windbreaks would play an important role, not only in raising traffic safety, but also in protecting agricultural fields and crops from strong winds. The importance of vegetation in the highway landscape, especially in the moments of extreme climate elements, can be invaluable (Lorenz, 1980).

Each section of the highway is very specific in terms of the impact of different climate elements, therefore, the highway should not be considered as a uniform and unique entity, but each section must be considered individually. Therefore, it is important to study climate elements at the micro level to see the real situation and determine the most dangerous sections and spots on the road. Consequently, in order to increase the traffic safety, knowing nature of various influences of climate elements, adequate measures for the regulation of the area could be provided.

Research of climate elements certainly does not end here. There are still questions to be answered. How strong is the impact of climate extremes on traffic safety? Can they be controlled by vegetation in the area of highway landscape? Are traffic accidents and the number of injured people correlated with the impact of climate extremes? How can the "black spots" on the highway, formed by joint influence of climate elements, be accurately located? The field of study of this segment of physical geography is wide enough and it is certainly necessary to work on this topic so that we can be sure that the roads we drive on are safe and secure. 


\section{References}

Alemu, M. M. (2016). Ecological Benefits of Trees as Windbreaks and Shelterbelts. International Journal of Ecosystem, 6(1), 10-13. doi:10.5923/j.ije.20160601.02.

Bergel-Hayat, R., Debbarh, M., Antoniou, C., \& Yannis, G. (2013). Explaining the road accident risk: weather effects. Accident Analysis \& Prevention, 60, 456-465. doi:10.1016/j.aap.2013.03.006.

Brijs, T., Karlis, D., \& Wets, G. (2008). Studying the effect of weather conditions on daily crash counts using a discrete time-series model. Accident Analysis \& Prevention, 40(3), 1180-119o. doi:10.1016/j. aap.2008.01.001.

Crowe, S. (1960). The landscape of roads. London: Architecture press.

Danube Floodrisk Project (2012). Atlas of flood hazard and risk maps of the Danube. Vienna: ICPDR Secretariat.

Doornkamp, J. C. (1985). The Earth Sciences and Planning in the Third World. Liverpool: University Press.

Dukić, D. (1998). Climatology. Belgrade: Faculty of Geography, University of Belgrade. (in Serbian)

Đorđević, J. (2004). Typology of physical-geographic factors in Spatial planning. Belgrade: Geographical institute „Jovan Cvijić" of Serbian Academy od Science and Arts. (in Serbian)

Edwards, J. (1996). Weather-related road accidents in England and Wales: a spatial analysis. Journal of Transport Geography, 4(3), 201-212. doi:10.1016/o9666923(96)00006-3.

Eisenberg, D. (2004). The mixed effects of precipitation on traffic crashes. Accident analysis \& prevention, 36(4), 637-647. doi:10.1016/Sooo14575(03)00085-X.

Franch-Pardo, I., Napoletano, B. M., Bocco, G., \& Barrasa, S. (2017). The Role of Geographical Landscape Studies for Sustainable Territorial Planning. Sustainability, 9(11), 2123. doi:10.3390/su9112123.

Gabler, S. P. (2015). Fundamentals of Physical Geography. Boston: Cengage Learning.

Havstad, K. M., Brown, J. R., Estell, R., Elias, E., Rango, A., \& Steele, C. (2018). Vulnerabilities of Southwestern US Rangeland-based animal agriculture to climate change. Climatic Change, 148(3), 371-386. doi:10.1007/s10584-016-1834-7.

Hermans, E., Brijs, T., Stiers, T., \& Offermans, C. (2006, Janury). The impact of weather conditions on road safety investigated on an hourly basis. In R. Gillum. (ed.), Proceedings of the Transportation Research Board 85th Annual Meeting (pp. 1-17), Washington DC, USA.

IPCC (2014). Climate Change 2014: Synthesis Report. Contribution of Working Groups I, II and III to the
Fifth Assessment Report of the Intergovernmental Panel on Climate Change [Core Writing Team, Pachauri, R.K. and Meyer, L.A. (eds.)]. IPCC: Geneva, Switzerland.

Kicošev, S. (2007). Geographical bases of spatial planning. Novi Sad: Faculty of Science. (in Serbian)

Kirkby, M. (2011). Hillslopes and landform evolution. In J. Holden (ed.), An Introduction to Physical Geography and the Environment (pp. 215-244). UK: Pearson Education Limited.

Koetse, M. J., \& Rietveld, P. (2009). The impact of climate change and weather on transport: An overview of empirical findings. Transportation Research Part D: Transport and Environment, 14(3), 205-221. doi:10.1016/j.trd.2008.12.004.

Košćal, M., Menković, Lj., Mijatović, M., \& Knežević, M. (2005). Geomorphological map of the Autonomous Province of Vojvodina 1: 200 ooo. Belgrade: Geozavod-Gemini. (in Serbian)

Kumar Dahal, R., Hasegawa, S., Masuda, T., \& Yamanaka, M. (2006). Roadside Slope Failures in Nepal during Torrential Rainfall and their Mitigation. Tokyo, Japan: Universal Academy Press, Inc.

Lalić, B., Mihailović, T. D., \& Podraščanin, Z. (2011). Future state of climate in Vojvodina and expected impact on crop production. Ratar. Povrt./ Field Veg. Crop Res., 48, 403-418. https://scindeks-clanci.ceon. rs/data/pdf/1821-3944/2011/1821-39441102403L.pdf. (in Serbian)

Lorenz, H. (1980). Designing and tracing roads and highways. Belgrade: IRO Građevinska knjiga. (in Serbian)

McClatchey, J. (2011). Regional and local climates. In J. Holden (ed.), Introduction to Physical Geography and the Environment (pp. 157-182). UK: Pearson Education Limited.

McHarg, L. I. (1995). Design with Nature, 25th Anniversary Edition. USA: Turtleback Books.

Moran, J. (2010). On roads a hidden history. UK: Profile books Ltd.

MULTILATERAL (1983). European agreement on main international traffic arteries (AGR) (with annexes and list of roads). Concluded at Geneva on 15 November 1975, Vol.1302, I-21618.

Musk, F. L. (2003a). Climate as a factor in the planning and design of new roads and motorways. In A. Perry \& L. Symons (eds.), Highway meteorology (pp. 18-38). London, New York, Tokyo, Melbourne, Madras: E \& FN SPON. An Imprint of Chapman \& Hall. Taylor \& Francis Books, Inc.

Musk, F. L. (2003b). The fog hazard. In A. Perry \& L. Symons (eds.), Highway meteorology (pp. 105-144). 
London, New York, Tokyo, Melbourne, Madras: E \& FN SPON. An Imprint of Chapman \& Hall. Taylor \& Francis Books, Inc.

Obaigwa Sagero, P., Shisanya, C., Ongoma, V., \& Weku Shilenje, Z. (2016). Numerical simulation of rainfall and temperature over Kenya using Weather Research and Forecasting-Environmental Modelling System (WRF-EMS). Geographica Pannonica, 2(2), 51-61. doi:10.18421/GP20.02-01.

Pantelidis, L. (2011). A critical review of highway slope instability risk assessment systems. Bulletin of Engineering Geology and the Environment, 70(3), 395400. doi:10.1007/s10064-010-0328-5.

Perry, A., \& Symons, L. (1994). The wind hazard in the British Isles and its effects on transportation. Journal of Transport Geography, 2(2), 122-130. doi:10.1016/o966-6923(94)90018-3.

RHSS - Republic Hydrometeorological Service of Serbia (2017c). Rainfall regime in Serbia 1961-1990. Retrieved on 09. August 2017. from http://www. hidmet.gov.rs/latin/meteorologija/klimatologija_ padav_rezim.php. (in Serbian)

Stojićević, G., Basarin, B., \& Lukić, T. (2016). Detailed bioclimate analysis of Banja Koviljača (Serbia). Geographica Pannonica, 20(3), 127-135. doi:10.18421/ GP20.03-01.

Stojsavljević, R., Božić, S., Kovačević, M., Bubalo Živković, M. \& Miljković, Đ. (2016). Influence of selected climate parameters on tourist traffic of Kopaonik and Zlatibor mountains (Republic of Serbia). Geographica Pannonica, 20(4), 208-219. doi:10.18421/GP20.04-03.

Official Gazette of the Republic of Serbia, No. 64/2015. Strategy of Road Safety in Republic of Serbia for the period from 2015 to 2020. (in Serbian)

Theofilatos, A., \& Yannis, G. (2014). A review of the effect of traffic and weather characteristics on roadsafety. Accident Analysis and Prevention, 72, 244256. doi:10.1016/j.aap.2014.06.017.

Thornes, J. E. (1989). A preliminary performance and benefit analysis of the UK national road ice prediction system. Meteorological Magazine, 118(1402), 93-99.

Trbić, G., Popov, T., \& Gnjato, S. (2017). Analysis of air temperature trends in Bosnia and Herzegovina. Geographica Pannonica, 21(2), 68-84. doi:10.18421/ GP21.02-01.

Vlatković, S. (1981). Determination of the optimal forestation in SAP Vojvodina in order to protect and improve the environment. PhD thesis. Belgrade: Faculty of Forestry, University of Belgrade. (in Serbian)

\section{Internet sources:}

Internet 1: Regional Spatial Plan of AP Vojvodina Referral map 2 (in Serbian), http://www.zavurbvo. co.rs/images/planovi/rppapv/2-2.jpg (07.02.2018).

Internet 2: Seismological survey of Serbia - Interactive map of the seismic hazards of Serbia, http://www. seismo.gov.rs/Seizmicnost/Karte_hazarda_l.htm (13.08.2017). (in Serbian) 